\title{
Pendidikan Kecakapan Hidup Melalui Pelatihan Pembuatan Kain Tenun di Pondok Pesantren Miftahul Huda Pabelan Kabupaten Semarang
}

\author{
Ma'as Shobirin \\ Universitas Wahid Hasyim Semarang \\ Email: maas.shobirin@unwahas.ac.id
}

\begin{abstract}
Abstrct: In the modern era, there are still many young people who dropped out of school, including at boarding school. Economic factor that make them could not be a formal education. Nevertheless, schools remains committed to make a breakthrough in order to provide life skills for students who drop out of school. Life skill education program through the manufacture of woven fabrics organized in boarding school Miftahul Huda Pabelan Kab. Semarang is expected to provide knowledge as well as to equip the students to have the skills to live. This activity involves several parties such as Home Industry "Afiq", the Ministry of Religious Kab. Semarang and Central Java MUI through the division of the economic empowerment of the people. Through these activities, students are expected to be able to make woven and develop it themselves.
\end{abstract}

Abstrak: Di era modern saat ini, masih banyak ditemukan generasi muda yang mengalami putus sekolah, termasuk di pondok pesantren. Faktor ekonomi yang menjadikan mereka tidak bisa mengenyam pendidikan formal. Meski demikian, pesantren tetap berkomitmen melakukan terobosan guna membekali kecakapan hidup bagi santri yang putus sekolah. Program pendidikan Life Skill melalui pembuatan kain tenun yang diselenggarakan di pondok pesantren Miftahul Huda Pabelan Kab. Semarang ini diharapkan mampu memberikan pengetahuan sekaligus membekali para santri agar memiliki keterampilan hidup. Kegiatan ini melibatkan beberapa pihak seperti Home Industri "Afiq", Kementerian Agama Kab. Semarang dan MUI Jawa Tengah melalui devisi pemberdayaan ekonomi umat. Melalui kegiatan ini, diharapkan santri mampu membuat kain tenun dan mengembangkannya sendiri.

Kata Kunci: Pendidikan, Kecakapan, Pesantren 


\section{PENDAHULUAN}

Pondok pesantren merupakan miniatur dalam kehidupan bermasyarakat. Keberadaan tersebut mengisyaratkan bahwa pesantren merupakan wahana aktualisasi bagi santri dalam mempersiapkan kehidupan di masa yang akan datang. Seiring derasnya arus arus globalisasi dan modernisasi, pesantren diharapkan bisa bertahan dan memantabkan dirinya sebagai lembaga pendidikan Islam yang mampu menjawab persoalan-persoalan yang muncul di masyarakat.

Masyarakat menilai bahwa pesantren semakin lama semakin berkembang pesat. Dengan sistem pendidikan yang berlaku di pesantren, seseorang dapat ikut serta membentuk pribadi muslim yang tangguh, harmonis, mampu mengatur kehidupan pribadinya, mengatasi persoalan-persoalannya, mencukupi kebutuhankebutuhannya serta mengendalikan dan mengarahkan kehidupannya (Ismail dkk, 2002: 39-49).

Lembaga pendidikan Islam mempunyai andil yang sangat besar untuk mengiringi prosesnya dalam menjalankan hidup. Karena dalam orientasinya, pendidikan Islam harus mampu menyiapkan sumber daya manusia yang tidak sekedar sebagai penerima arus informasi global, juga harus memberikan bekal kepada mereka agar mengolah, menyesuaikan dan mengembangkan segala hal yang diterima melalui arus informasi itu, yakni manusia yang kreatif, dan produktif (Faisal, 1995: 131).

Proses menuju ke arah kreatif dan produktif, dibutuhkan langkah nyata dari pihak pesantren sebagai bentuk keseriusan dalam mencetak santri yang memiliki kreatifitas dan produktifitas. Lulusan pesantren tidak sekadar mampu memahami dan menguasi persoalan keagamaan, namun kemampuan dalam menguasai kecakapan hidup perlu dirumuskan.

Amin Haedari menjelaskan bahwa pesantren perlu melakukan langkah stratgeis sebagai berikut: pertama, membuat kurikulim terpadu, gradual, sistematik, egaliter, dan bersifat buttom up (tidak top down). Artinya, penyusunan kurikulum tidak lagi didasarkan pada konsep plain for student (pembiasaan untuk santri) tapi plain by student (pembiasaan oleh santri). Kedua, melengkapi sarana penunjang proses pembelajaran. Ketiga, memberikan kebebasan kepada santri yang ingin mengembangkan talenta mereka masingmasing, baik yang berkenaan dengan pemikiran, ilmu pengetahuan, teknologi, maupun kewirausahaan. Keempat, menyediakan wahana aktualisasi diri di tengahtengah masyarakat (haedari, 2004: 198-199).

Saat ini, pendidikan masih dianggap mahal untuk sebagian kalangan santri di pedesaan. Akibatnya, sebagian anak tidak mampu melanjutkan pendidikan yang lebih tinggi. Putus sekolah dan memperdalam ilmu agama di pondok 
pesantren menjadi solusi terakhir. Oleh karena itu, permasalahan ini harus diperhatikan oleh pimpinan pesantren untuk tidak tinggal diam dalam upaya mengembangkan potensi dan kreatifitas para santri.

Disadari bahwa kecenderungan untuk mengembangkan pengetahuan non agama di pesantren merupakan kebutuhan nyata yang harus dihadapi para lulusan pesantren di masa depan. Justru tantangan untuk berlomba menguasai pengetahuan non agama merupakan salah satu tugas yang harus dilaksanakan oleh pondok pesantren (Anwar: 2006: 72). Diharapkan pesantren tidak sekadar tempat untuk belajar ilmu agama saja, melainkan dapat memberikan media aktualisasi dalam upaya pengembangan kemandirian dan kreatifitas santri. Kelak dapat menjadi bekal berharga untuk kehidupan mendatang.

Fokus pendampingan pada program pelatihan ini adalah bagaimana santri diajarkan untuk dapat membuat kain tenun, khususnya bagi santri yang memiliki keterbatasan ekonomi yang meliputi; 1) Menumbuhkan jiwa kewirausahaan pada diri santri dalam upaya mempersiapkan bekal untuk kelangsungan hidup di masa depan; 2) Pelatihan mendesain pola kain ikat tenun dan praktik cara pembuatannya dan 3) Produksi hasil pelatihan.

Manfaat dari kegiatan ini diharapkan 1) Mampu menggali potensi serta mengembangkan jiwa enterpreneurship di lingkungan pondok pesantren salaf; 2) Mengembangkan Life skill guna melengkapi kompetensi santri salaf untuk terjun di dunia nyata atau kerja; 3) Menjadikan pesantren Miftahul Huda sebagai pesantren objek percontohan di wilayah Kab. Semarang dalam hal pengembangan program Life Skill di lingkungan pondok pesantren, 4) Santri lulusan dari program pelatihan ini diharapkan dapat memproduksi kain ikat tenun secara mandiri; 4) Meningkatkan kemandirian santri serta menghidupkan roda perekonomian pesantren salaf untuk menopang keberlangsungan pesantren di masa mendatang.

\section{KONDISI SUBJEK PENDAMPINGAN}

Pondok pesantren Miftahul Huda merupakan lembaga pendidikan pesantren yang terletak di Desa Padaan Kecamatan Pabelan Kabupaten Semarang. Pesantren ini sangat jauh dari keramaian kota. Untuk mencapai lokasi, kurang lebih berjarak $7 \mathrm{~km}$ dari jalan utama Ungaran-Salatiga. Keadaan jalan menuju ke arah pondok tersebut terbilang tidak terlalu baik. Masyarakat berharap bahwa pesantren ini dapat menjadi tempat untuk belajar santri agar mereka memiliki keteguhan dalam beragama serta dapat membentuk pribadi yang terampil dan mandiri. 
Pesantren yang didirikan oleh K. Zaini Zulfa semakin menjadi salah satu lembaga yang diharapkan dapat merubah pola pikir masyarakat di wilayah tersebut. Perjuangan yang dilakukan oleh beliau mendapatkan dukungan dari seluruh lapisan masyarakat. Didirikannya pesantren dimaksudkan untuk menjadi jembatan ilmu bagi masyarakat sekitar. Meski secara fisik kondisi pondok pesantren belum memadai, namun pengajaran di pesantren berjalan dengan baik.

Dari data yang dapat oleh tim pendamping, jumlah santri yang bermukim di pesantren tersebut berjumlah 102 santri. Dari sekian banyak santri yang bermukim, rata-rata memiliki latar belakang ekonomi yang lemah. Kenyataan ini bisa dilihat masih terdapat 27 santri yang belum mampu melanjutkan ke jenjang yang lebih tinggi, khususnya di Madrasah Aliyah.

Keadaan ekonomi keluarga para santri di sana, menggerakkan hati $\mathrm{K}$. Zaini Zulfa untuk serius mendampingi dan memberikan perhatian penuh pada mereka. Bahkan, bagi para santri yang berasal dari keluarga miskin tidak dipungut biaya apapun selama tinggal di pesantren tersebut. Keterpanggilan ini kemudian diikuti dengan usaha kuat dari pihak pesantren dalam merencanakan program pendidikan kecakapan hidup bagi santri. melalui program ini diharapkan santri dapat memiliki bekal keterampilan sehingga menumbuhkan jiwa kemandirian mereka.

\section{KEGIATAN PELATIHAN PEMBUATAN KAIN TENUN}

Kegiatan ini dilaksanakan pada tanggal 30 September sampai 10 Desember 2015 yang bertempat di Aula pondok pesantren Miftahul Huda Kecamatan Pabelan Kabupaten Semarang. Kegiatan pelatihan pembuatan kain tenun bagi santri putus sekolah dilakukan dua kali dalam satu minggu, yaitu pada hari jum'at dan sabtu. Kegiatan berlangsung mulai dari jam 09.00- 15.00 Wib yang bersifat teori maupun praktik.

Dalam melaksanakan kegiatan ini, tim pengabdian tidak dapat menjalankannya sendiri, melainkan perlu adanya mitra kerjasama pihak lain. Beberapa pihak terlibat dalam kegiatan ini antara lain adalah sebagai berikut;

a. Pengelola dan Pimpinan Pondok Pesantren Miftahul Huda.

Pihak Pondok Pesantren memilki peran penting dalam penyelenggaraan ini, selain menjadi tempat pelatihan, phak pesantren mensosialisasikan program kepada para santri yang putus sekolah untuk bisa mengikuti acara tersebut dengan cara melakukan seleksi. Pihak pesantren juga membantu dalam mempersiapkan sarana pelatihan agar proses berjalannya program dapat berjalan dengan lancar dan sesuai harapan tim pelaksana.

b. Home Industri Kain Tenun Troso "AFIQ” 
Pihak yang berperan paling penting dalam kegiatan ini adalah Home industri Kain Tenun Ikat Troso "AFIQ" yang beralamat di Desa Troso Rt.04 Rw.07 Pecangan Jepara. Lembaga ini merupakan salah satu pusat pengrajin kain tenun. Lembaga ini bertugas untuk membantu pelaksana dalam memberikan bekal pengetahuan dan keterampilan santri dalam membuat kain tenun troso. Lembaga ini telah banyak memberikan pendamping bagi lembaga lain yang membutuhkan jasanya. Pendampingan intens dilakukan untuk melatih pembuatan kain tenun dmulai dari proses awal hingga produk siap dipasarkan.

c. Kementerian Agama Kab. Semarang dan MUI Jawa Tengah

Kementrian Agama Kab. Semarang dan MUI Jawa Tengah Devisi Pemberdayaan Ekonomi Umat memiliki peran dalam mengawal kegiatan ini hingga akhir. Selain itu, diberikan kepercayaan untuk memberikan materi tentang wirausaha di dunia pesantren. Selain itu, pihak kementerian agama diharapakan lebih memperhatikan perkembangan pesantren pada bidang wirausaha, tidak sekedar memperhatikan dalam proses pendidikan yang ada di pesantren. Dengan demikian, kemandirian pesantren secara perlahan akan muncul, dan akan berdampak pada proses perkembangan dan kemajuan pesantren.

Kegiatan yang dilaksanakan meliputi kegiatan persiapan (pra), tahap pelaksanaan dan evaluasi. Pertama, Tahap Pra-Pelaksanaan. Pada tahap ini, selaku tim sangat intens melakukan diskusi tenang beberapa hal yang akan dilakukan selama kegiatan. Pasalnya, kami menyadari betul bahwa perencaan ini menjadi bagian yang sangat penting dalam menentukan keberhasilan program. Beberapa pertemuan dilakukan untuk menentukan desain pelatihan. Bahkan pelaksana juga mendatangnya trainer untuk membantu mendesain materi pelatihan dari awal sampai akhir kegiatan.

Selanjutnya, dilakukan kerjasama dengan berbagai pihak dengan harapan agar kegiatan ini dapat berjalan secara maksimal dan sesuai dengan target yang diharapkan. Keterlibatan beberapa pihak yang sudah disebutkan di atas sangat menentukan proses berlangsungnya kegiatan ini selama tiga bulan kedepan.

Dalam rangka mencapai target yang diharapkan, strategi yang dilakukan adalah melaksanakan program pelatihan ini secara intensif dan melakukan beberapa langkah strategi. Adapun strategi yang dapat dilakukan antara lain;

1) Melakukan kerjasama dengan pihak pengelola pesantren dalam pelaksanaan program. 
2) Mensosialisasikan keberadaan program pelatihan pada santri, terutama yang akan dijadikan sebagai subjek pendampingan dalam adalah santri yang putus sekolah.

3) Memberikan bekal pengetahuan atau teori tentang pentingnya kemandirian ekonomi dan pentingnya pengembangan life skill di lingkungan pondok psantren.

4) Penyediaan sarana dan prasarana untuk menunjang program pelatihan pembuatan kain tenun.

5) penjadwalan dan pengelompokan peserta pelatihan disusun guna mempermudah tim pelaksana dalam melakukan pendampingan program pelatihan.

6) Praktik pembuatan kain ikat tenun melalui dari konsep dasar sampai pada hasil produk kain ikat tenun.

Kedua, Tahap Pelaksanaan. Secara berurutan meliputi Acara Pembukaan. Pelaksanaan kegiatan di mulai dengan acara pembukaan di akhir bulan september 2015. Kegiatan pembukaan dilaksanakan di aula pondok pesantren Miftahul Huda Pabelan Kab. Semarang. Seluruh peserta kegiatan yang terdiri dari 25 santri ikut memeriahkan acara pembukaan. Pada acara tersebut dihadiri oleh pengelola poondok pesantren Miftahul Huda (K. Zaini Zulfa), Kasi Pekapontren Kementerian Agama Kabupaten Semarang (Ahmad Thoha) dan delegasi dari MUI.

Nur Cholid dalam sambutannya menjelaskan, kegiatan ini merupakan bentuk perhatian Unwahas kepada dunia pendidikan Islam, khusunya pesantren. "Saya berharap, para santri bisa secara maksimal mengikuti pelatihan dan kelak melahirkan santri dan kiai yang mandiri," jelas Dekan FAI Unwahas.

Senada dengan Cholid, Taslim Syahlan mengatakan bahwa kegiatan ini merupakan implementasi dari Tri Darma Perguruan Tinggi. Tidak hanya mengajar mahasiwa di kampus, para dosen juga melakukan penelitian dan pengabdian masyarakat. Selain menggunakan dana hibah dari Kemenag, kegiatan ini juga akan melibatkan MUI Jateng.

Sementara itu pengasuh pesantren Miftahul Huda, KH. Zaini Zulfa menceritakan, para santri-nya dating dari berbagai daerah di Indonesia. Ada yang berasal dari Papua, Kalimantan dan Sumatera, selain mayoritas dari Pulau Jawa sendiri. Mereka umumnya siswa yang memiliki keterbatasan dalam hal finansial, sehingga tida kuat membayar biaya sekolah. Walhasil, biaya sekolah mereka menjadi beban pesantren dan kiainya.

Pihak Kemenag Kabupaten Semarang menyambut baik inisiatif dari Unwahas yang melibatkan pesantren kecil dan berada di daerah pinggir, seperti 
pesantren Miftahul Huda ini. "Kegiatan ini sangat membantu dalam mendidik santri yang kurang beruntung, baik secara finansial maupun dalam hal pendidikan", jelas Ahmad Thoha dalam sambutannya.

Dilanjutkan dengan Pembuatan Kain Tenun. Secara garis besar, proses awal tenun dibagi menjadi dua, yaitu proses menyiapkan benang lungsi dan proses penyiapan benang pakan. Pertama, pembuatan benang lungsi. Karena yang kita pelajari adalah ikat pakan, maka proses membuat benang pakan akan lebih panjang dan rumit. Biar lebih mudah, kita pelajari dahulu bagaimana cara membuat benang lungsi.

Benang tenun untuk lungsi yang dibeli di toko benang umumnya dalam ukuran 1 pack seberat $5 \mathrm{~kg}$. Benang yang digunakan beragam merk dan kualitasnya. Benang lungsi ini diwarnai terlebih dahulu melalui proses pewarnaan yang disebut menter, artinya memberi pewarna. Menter benang lungsi tidak rumit, karena hanya satu warna yang nanti setelah jadi kain menjadi warna dasar. Jadi cukup dicelupkan pewarna, diperas lalu dijemur sambil sesekali direnggangkan biar benangnya tdak ruwet.

Setelah kering, benang lungsi yang sudah berwarna ini dibawa kepada pekerja untuk proses nyepul. Nyepul atau memasukkan benang ke dalam sepulan kecil-kecil. Alat untuk menyepul ini dinamakan Jontro. Jontro tradisional dibuat dari velg sepeda yang dimodifikasi dan diputar dengan tangan. Menyepul biasanya dilakukan oleh kaum wanita karena butuj ketelitian.

Setelah semua benang lungsi berada dalam sepulan, sepulan ini di bawa ke bagian Sekir. Sepulan disusun ditempatnya dan dipindahkan ke BUM menggunakan alat yang disebut sekiran. Proses yang disebut nyekir ini menghasilan bum yang terisi benang lungsi. Sampai tahap ini, pembuatan benang lungsi hampir selesai, tinggal memasang bum yang telah berisi benang lungsi ke dalam alat tenun bukan mesin (ATBM) yang diteruskan dengan proses memasukkan benang lungsi ke dalam Sisir yang disebut Nyucuk. Nyucuk dilakukan dua orang, satu orang memasukkan benang dan satunya menarik benang yang masuk dari arah sebaliknya. Setelah itu benang lungsi sudah siap ditenun.

Selanjutnya mempersiapkan benang pakan. Benang tenun untuk pakan disiapkan terlebih dahulu. Kualitas benang berbeda-beda. Secara garis besar ada dua jenis yaitu katun biasa dan katun mercerised. Ada juga yang menggunakan benang jenis lain seperti rayon, polyester, atau viscos. Benang tenun pakan dipasangkan pada sepulan melalui proses nyepul menggunakan Jontro. Proses ini sama seperti proses menyepul pada benang lungsi. Bedanya, benang yang terpasang pada sepulan kali ini dibawa ke tempat proses ngeteng, Proses 
ngeteng, benang pakan yang tersusun dipasangkan pada alat segi empat yang disebut Plankan. Hasilnya, benang pakan terpasang rapi berjajar. Pada plankan inilah digambar motif atau sketsa yang nantinya menjadi motif dalam kain tenun.

\section{MEMBUAT CORAK KAIN TENUN}

Setelah selesai dibuat sketsa corak plankan dibawa ke pekerja ikat. Beberapa bagian diikat dengan warna tali rafia yang berbeda. Proses mengikat merupakan proses unik yang tidak ditemukan pada kain tradisional lain. Tidak heran, orang Barat sering menyebut kain tenun dengan sebutan Ikat. Dari proses ikat, benang dilepas dari plankan dalam kondisi masih terikat bagian bagiannya dan dilakukan proses pewarnaan yang disebut Menter. Warna yang diberikan pertama kali adalah warna paling gelap. Alasannya, warna pertama ini akan juga dicelupkan ke warna kedua sehingga warna pertama lebih gelap dari warna kedua.

Selesai warna pertama, kain tenun dijemur sampai kering. Kalau cuaca tidak panas, menjemur bisa memakan waktu berhari-hari. Setelah kering, baru proses pewarnaan kedua disiapkan. Caranya, bagian yang akan diwarna menggunakan warna kedua dipotong simpul ikatannya yang disebut proses mbatil yang dilanjutkan proses ngopesi atau mengupas yaitu melepas tali rafia pada bagian yang akan diwarna menggunakan warna kedua. Baru dah, benang dicelupkan pada pewarna kedua, dan dijemur lagi.

Proses mengikat, mencelupkan pewarna, menjemur, dan melepaskan ikatan, dilakukan berulang-ulang sesuai ragam warna corak yang dikehendaki. Terkadang, proses ini juga menggunakan teknik tali ulang, gosokan dan teknik pewarnaan sekunder lain.

Ketiga, Tahap Evaluasi. Evaluasi program dilakukan oleh trainer yang selama pelatihan mendidik untuk membuat kain ikat tenun. Pada tahap akhir peserta melakukan praktik pembuatan kain ikat tenun. Tidak hanya itu, peserta juga diuji kemampuan mereka dalam mendesain dan melakukan praktik persiapan sebelum membuat kain ikat tenun. Alhamdulillah, hasilnya memuaskan dn rata-rata para santri mampu membuat kain tenun meski masih dalam pola sederhana.

\section{KESIMPULAN}

Kegiatan yang diikuti oleh 25 santri di pondok pesantren Miftahul huda pabelan kab. Semarang yang berlangsung selama hampir tiga bulan. Mereka dilatih dengan serius agar dapat memproduksi kain ikat tenun sebagai tambahana 
kemampuan life skill. Pada hakikatnya, seluruh kegiatan berjalan dengan baik. Kebanyakan santri merasa senang mengikuti program ini. Seluruh materi tersampaikan dengan baik dan alhamdulillah target dapat diperoleh dengan hasil yang memuaskan. Meski masih taraf pemula, minimal mereka mampu memahami alur bagaimana cara membuatnya sekaligus mempraktikkannya.

Materi pelatihan yang disajikan seperti; 1) Praktik penyiapkan benang lungsi dan pakan; 2) Praktik proses pewarnaan; 3) Praktik proses penyepulan; 4) Praktik proses penyekiran, 5) Praktik proses penyucukan; 6) Praktik proses ngenteng; 7) Praktik proses pembuatan corak kain tenun; 8) Praktik proses mengikat; 9) Praktik proses menter; 10) Praktik proses Mbatil; 11) Praktik proses Ngopesi; dan 12) Produk Hasil, dapat diikuti dan dipahami dengan baik oleh peserta pelatihan.

Kegiatan ini tidak bersifat temporal, melainkan memiliki output yang jelas sebagai hasil dari pelatihan. Setidaknya pasca pelatihan ini, mereka dapat membuat kain ikat tenun dan prosesnya akan berada di bawah bimbingan pengelola pesantren. Selain itu, hasil dapat mencapai target yang diharapkan sehingga luaran dari program tersebut bisa menjadi bagian dari aset usaha pesantren. Langkah pendamping juga akan menawarkan program kerjasama untuk mendapatkan zakat dari perusahaan yang peduli dengan pengembangan pesantren.

\section{SUMBER DATA}

Anwar, Pendidikan Kecakapan Hidup (Life Skill Education) Konsep dan Aplikasi, (Bandung: Alfabeta, 2006.

Dokumentasi Pengurus Pondok Pesantren Miftahul Huda Kecamatan Pabelan Kabupaten Semarang.

Faisal, Jusuf Amir, Reorientasi Pendidikan Islam,(Jakarta: Gema Insani Press, 1995

Haedari, Amin., dkk, Masa Depan Pesantren dalam Tantangan Modernitas dan Tantangan Kompleksitas Global, Jakarta: IRD Press, 2004.

Hasil wawancara dengan K. Zulfa (Pengasuh Pondok Pesantren Miftahul Huda) di rumah kediaman pada tanggal 10 Oktober 2015. 
Hasil wawancara dengan Rofiq, Trainer Afiq pada tanggal 2 Oktober 2016.

Ismail SM, dkk., Dinamika Pesantren dan Madrasah, Yogyakarta: Pustaka Pelajar Bekerja Sama dengan Fakultas Tarbiyah IAIN Walisongo Semarang, 2002 